\title{
Izgorelost in samoučinkovitost strokovnih delavk v vrtcu
}

\author{
Sonja Čotar Konrad \\ Univerza na Primorskem \\ sonja.cotarkonrad@pef.upr.si \\ Maja Lebeničnik \\ Univerza na Primorskem \\ maja.lebenicnik@pef.upr.si
}

\begin{abstract}
V raziskavi smo ugotavljali stopnjo izgorelosti in občutka samoučinkovitosti pomočnic vzgojitelja predšolskih otrok v vrtcu. Zanimale so nas tudi razlike v merjenih konceptih med pomočnicami različnih starostnih skupin otrok, ki so na različni stopnji profesionalnega razvoja. Ugotovljamo, da je poročana stopnja izgorelosti razmeroma nizko izražena, saj pomočnice kažejo visoko stopnjo osebne izpolnitve na delovnem mestu ter nižjo stopnjo čustvene izčrpanosti in depersonalizacije. Poročajo tudi o razmeroma visokem občutku samoučinkovitosti, pri čemer se kažejo razlike glede njenih komponent: pomočnice, ki delujejo v prvi starostni skupini (otroci starosti od 1 do 3 leta), ugodneje ocenjujejo občutek samoučinkovitosti na področju spodbujanja motivacije otrok kot pomočnice, ki delajo z drugo starostno skupino otrok (3-6 let starosti). Poročana samoučinkovitost je različna tudi glede na stopnjo profesionalnega razvoja, pri čemer pomočnice začetnice (do 3 let delovne dobe) občutijo najnižjo stopnjo samoučinkovitosti na delovnem mestu, pomočnice $v$ fazi poklicne stabilizacije pa najvišjo stopnjo samoučinkovitosti.
\end{abstract}

Ključne besede: izgorelost, samoučinkovitost, pomočnice vzgojitelja predšolskih otrok, profesionalni razvoj

\section{Uvod}

V zadnjih desetletjih zahteve do pedagoških delavcev naraščajo, kar lahko pomeni povečano tveganje zaposlenih za izgorelost. Nekatere študije (Košir idr. 2014; Slivar 2013) kot najpogostejše stresorje pedagoških delavcev navajajo tako strukturne (npr. prevelike skupine, pomanjkanje opreme, preveč administrativnega dela) kot tudi procesne dejavnike (npr. težave $v$ odnosu $z$ otroki/učenci, s starši in sodelavci) ter druge sistemske vidike njihovega dela (način vodenja, status poklica v družbi itd). Študije izgorelosti poleg organizacijskih dejavnikov pogosto poudarjajo tudi vlogo osebnostnih značilnosti (npr. motivacije, prepričanj, emocionalne inteligentnosti ipd.) in interakcij le-teh z organizacijskimi dejavniki na delovnem mestu. V okviru omenje- 
nih ugotovitev lahko sklepamo, da je delo pomočnika vzgojitelja predšolskih otrok ( $v$ nadaljevanju pomočnice) še posebej kompleksno in $z$ vidika tveganja za izgorelost rizično. V skladu z določili Zakona o vrtcih (2005) ${ }^{1}$ se namreč naloge pomočnic nanašajo predvsem na sodelovanje, pomoč in podporo vzgojitelju predšolskih otrok, ki na področjih načrtovanja, izvajanja in priprave vzgojnega dela, uporabe in oblikovanja didaktičnega materiala itd. lahko v celoti določa zahteve in pričakovanja do pomočnice. Slednje lahko od pomočnic zahteva ne zgolj odzivanje na potrebe otrok v skupini in njihovih staršev, ampak tudi povečano občutljivost in odprtost za sodelovanje z vzgojiteljem. Omenjeno lahko v primerjavi s položajem delovnega mesta vzgojitelja predšolskih otrok že $v$ izhodišču pomeni nižji poklicni status v vzgojno-izobraževalni ustanovi, slabše plačilo in veliko obremenjenost pomočnic. Predvidevamo torej lahko, da so različni dejavniki na delovnem mestu pomočnic zanje manj ugodni, kar posledično lahko vodi k višjemu tveganju za izgorelost.

\section{Izgorelost}

Posameznik lahko kot odgovor na kronični stres na delovnem mestu razvijejo psihološki sindrom izgorelosti, ki negativno vpliva na njihovo delovno, telesno in psihološko funkcioniranje. Najširše uveljavljeni model izgorelosti je model C. Maslach in S. E. Jackson (1981), ki zajema tri komponente: čustveno izčrpanost, depersonalizacijo in osebno izpolnitev. Po tem modelu izgorelost pri posamezniku ni zgolj bodisi prisotna ali odsotna, ampak ima razpon od nizko ter zmerno do visoko izraženih občutij. Na visoko izgorelost kažejo kombinacija visoke čustvene izčrpanosti, visoke depersonalizacije in nizke osebne izpolnitve (Maslach, Schaufeli in Leiter 2001).

Čustvena izčrpanost predstavlja osrednjo komponento izgorelosti. Pri visoko čustveno izčrpanem posamezniku so močno in pogosto prisotni občutki čustvene utrujenosti, preobremenjenosti in pomanjkanja fizične ter psihološke energije za delo. Čustvena izčrpanost sčasoma vodi v način dela, za katerega sta značilna čustvena in miselna odmaknjenost od dela ter otopel,

\footnotetext{
'Zakon o vrtcih (2005) v 41. členu predvideva, da delovna obveznost vzgojitelja obsega pripravo na vzgojno delo, načrtovanje in izvajanje vzgojnega dela, delo s starši ter sodelovanje pri organizaciji življenja in dela v vrtcu. Delovna obveznost vzgojitelja predšolskih otrok - pomočnika vzgojitelja obsega sodelovanje z vzgojiteljem pri načrtovanju, izvajanju in pripravi vzgojnega dela v oddelku, samostojno izvajanje nekaterih dejavnosti predšolske vzgoje ter sodelovanje pri ostalih dejavnostih in opravljanje drugih nalog, povezanih z dejavnostjo vrtca. V okviru z zakonom in kolektivno pogodbo določenega polnega tedenskega delovnega časa vzgojiteljevo delo z otroki obsega 30 ur, delo vzgojitelja predšolskih otrok - pomočnika vzgojitelja pa 35 ur tedensko.
} 
neobčutljiv in odklonilen odnos do oseb, $s$ katerimi zaposleni prihaja $v$ stik pri svojem delu, kar C. Maslach in S. E. Jackson (1981) imenujeta depersonalizacija (tudi cinizem). Tretja opredeljujoča sestavina izgorelosti je znižana osebna izpolnitev, kar pomeni, da posameznik občuti pomanjkanje kompetentnosti in produktivnosti na delovnem mestu (npr., čuti se nesposobnega, neprimernega za specifično delovno mesto). Model izgorelosti predvideva, da je čustvena izčrpanost predhodnica depersonalizacije, obe skupaj pa pripeljeta do nizke osebne izpolnitve (Depolli Steiner 2011). Nekateri avtorji pri preučevanju izgorelosti obravnavajo le dve komponenti izgorelosti, in sicer izraženost čustvene izčrpanosti ter depersonalizacijo (Aloe, Amo in Shanahan 2014), vendar pa so statistične analize pokazale večjo primernost trifaktorskega kot dvofaktorskega modela izgorelosti za različne poklicne skupine (Bakker, Demerouti in Schaufeli 2002; Maslach, Schaufeli in Leiter 2001).

Izgorelost so sprva povezovali z zahtevnimi čustvenimi situacijami, ki so jim izpostavljeni predvsem zaposleni v službah pomoči in storitvenih dejavnostih, ki morajo pogosto zadovoljevati potrebe ali reševati probleme prejemnikov svojih storitev (npr. strank, pacientov, učencev itd.) (Maslach, Schaufeli in Leiter 2001). Takšno delo je povezano s tveganjem, da se posameznik čustveno izčrpa (Maslach 2003). Kasneje pa sta C. Maslach in Leiter (1997, v Maslach, Schaufeli in Leiter 2001) poudarila, da je izgorelost posledica kroničnega neujemanja med osebnostjo in zahtevami delovnega mesta ter se pojavlja v vseh poklicih.

Raziskovalci izgorelosti (Maslach, Schaufeli in Leiter 2001) zato že dolgo poudarjajo, da so, poleg osebnih značilnosti, tudi organizacijske značilnosti (npr. socialna klima, pomanjkanje nagrad, delovne obremenitve, premalo nadzora nad lastnim delom ipd.) med pomembnimi dejavniki, ki prispevajo $\mathrm{k}$ izgorelosti na delovnem mestu. Intervencije za zmanjševanje in preprečevanje izgorelosti so zato vezane tako na posameznika (npr. treningi emocionalnih kompetenc, učenje veščin asertivnosti, sproščanja, spoprijemanja s stresom itd.) kot na organizacijo (npr. razvijanje sodelovalne klime, spodbujanje pravičnosti in enakopravnosti itd.).

\section{Izgorelost pedagoških delavcev}

Pedagoški delavci se na vseh stopnjah šolskega sistema pogosto soočajo $s$ stresorji, ki so medosebne, čustvene in organizacijske narave, zato se med njimi pojavlja tudi izgorelost. Raziskave o slovenskih pedagoških delavcih (Demšar 2003 v Slivar 2009; Depolli Steiner 2011; Slivar 2009) neprekinjeno kažejo, da okrog $10 \%$ pedagoških delavcev poroča o visoki, $25 \%$ do $40 \%$ pa o zmerni izgorelosti. Na osnovi primerjave raziskav je opaziti tudi trend nara- 
ščanja zmerne ter nižanje deleža nizke izgorelosti, pri čemer se - po raziskavi K. Depolli Steiner (2011) - proces izgorelosti še ni pričel le pri $5 \%$ slovenskih pedagoških delavcev.

Ob tem je pomembno tudi dejstvo, da pedagoški delavci, ki so visoko izgoreli, drugače zaznavajo svoje učence, z njimi vzpostavljajo drugačne, manj ustrezne odnose in ustvarjajo manj ugodno učno okolje (Depolli Steiner 2011). Raziskovalka podrobneje ugotavlja, da se pedagoški delavci, ki so $\checkmark$ večji meri čustveno izčrpani, čutijo kronično utrujene in imajo občutek, da svojim učencem s pedagoško-psihološkega vidika ne zmorejo »dati toliko, kot s[m]o jim nekoč«. Zagotavljanje ustreznega odnosa in procesa med pedagoškim delavcem in učencem je namreč ena ključnih nalog pedagoškega delavca in in eno ključnih pričakovanj učencev $v$ »dobri šoli«, ki - kot pravi S. Rutar (2018) - od učiteljev pričakujejo spodbudo, podporo in pomoč, česar pa izgoreli učitelj ne (z)more. Pedagoški delavci tako postopoma izgubljajo pozitivno naklonjenost do svojih učencev in do njih oblikujejo negativnejša stališča, kar se kaže kot eden pomembnih elementov izgorelosti, to je depersonalizacija (Maslach, Schaufeli in Leiter 2001). Pedagoški delavci, ki na delovnem mestu doživljajo slednjo, svoje učence pogosteje označujejo, žalijo, so do njih kritičnejši, hladnejši in povečajo fizično distanco (Maslach, Jackson in Leiter 1997; Maslach, Schaufeli in Leiter 2001). Dokazano je bilo tudi, da občutek depersonalizacije pedagoškega delavca na vedenjske težave $v$ razredu vpliva tudi posredno, preko znižanega entuziazma, ki ga pedagoški delavci občutijo ob opravljanju svojega dela (Benita, Butler in Shibaz 2019). Skaalvik in Skaalvik (2010) poročata, da so pri pedagoških delavcih posamezne dimenzije izgorelosti povezane $z$ različnimi kontekstualnimi dejavniki. Tako npr. težavni odnosi s starši pozitivno napovedujejo depersonalizacijo pedagoškega delavca, časovna stiska pri delovnih zadolžitvah pa čustveno izčrpanost.

Kljub temu, da je delovno mesto strokovnega delavca $v$ vrtcu, $v$ večji meri kot delo učiteljev, neposredno povezano z zadovoljevanjem psihofizičnih potreb otrok ter uravnavanjem njihovega vedenja in je obenem tudi socialno-statusno ter finančno pogosto nižje ovrednoteno (Tsai, Fung in Chow, 2006), so raziskave izgorelosti pedagoških delavcev pogosteje izvedene na populaciji učiteljev. Čeprav se izgorelost na predšolski stopnji ne preučuje pogosto (Rentzou 2015), nekateri raziskovalni izsledki (Baran idr. 2010; Radic Hozo, Sucic in Zaja 2015; Al-Adwan in Al-Khayat 2017; Jeon, Buettner in Ashley 2018) kažejo, da bi bilo to potrebno in smiselno. E. Radic Hozo, G. Sucic in I. Zaja (2015) tako npr. ugotavljajo, da približno polovica vzgojiteljic kaže znake izgorelosti na delovnem mestu, novejše študije (Jeon, Buettner in 
Ashley 2018) pa poročajo o povezanosti občutka samoučinkovitosti in organizacijskih dejavnikov delovnega mesta s čustveno izčrpanostjo strokovnih delavk vrtca (Al-Adwan in Al-Khayat 2017). Nadalje raziskave kažejo tudi to, da vzgojitelji v primerjavi z osnovnošolskimi učitelji poročajo o višje izraženi depersonalizaciji in nižji osebni izpolnitvi, medtem ko pri čustveni izčrpanosti ne prihaja do razlik med omenjenimi skupinami pedagoških delavcev (Baran idr. 2010). Podobno kažejo rezultati študije na slovenskih strokovnih delavcih v vrtcu, ki v primerjavi z učitelji kot nekoliko stresnejše zaznavajo odnose na delovnem mestu (s sodelavci v skupini in z vodstvom) (Rutar 2019).

\section{Pomanjkanje študij na področju izgorelosti strokovnih delavk v vrtcu}

Nekatere slovenske študije pa poročajo o nasprotujočih si rezultatih v zaznavanju stresa in izgorelosti v vrtcu glede na delovno mesto strokovnih delavk. Tako npr. Slivar (2009) ugotavlja, da vzgojiteljice v primerjavi s pomočnicami vzgojiteljic občutijo več stresa zaradi administrativnih zahtev dela in pomanjkanja podpore pri delu, medtem ko V. Rutar (2019) poroča, da pomočnice vzgojiteljic doživljajo več stresa kot vzgojiteljice zaradi pomanjkanja podpore znotraj vrtcev. O razlikah v poročani stopnji doživljanja stresa in izgorelosti strokovnih delavk glede na starostno skupino, $v$ kateri delajo, pa poroča K. Rentzou (2015), ki je na grškem vzrocu strokovnih delavk v vrtcih ugotovila, da zaposleni, ki delajo $z$ drugo starostno skupino (starost otrok od 3 do 6 let) občutijo višjo čustveno izčrpanost v primerjavi z zaposlenimi, ki delajo s prvo starostno skupino (starost otrok 1 do 3 let). Po drugi strani strokovne delavke pri prvih starostnih skupinah izražajo močnejši občutek depersonalizacije kot vzgojitelji drugih starostnih skupin (Rentzou 2015).

Vzrok za izgorelost je mogoče iskati v prepletu organizacijskih in osebnostnih dejavnikov, zato se med osebnostnimi dejavniki v zvezi z izgorelostjo pedagoških delavcev pogosto preučuje tudi njihova samoučinkovitost.

\section{Samoučinkovitost kot osebnostni dejavnik izgorelosti}

Samoučinkovitost je Bandura (1986) opredelil kot posameznikovo prepričanje o lastnih sposobnostih za učinkovito izvedbo določene aktivnosti. Občutek samoučinkovitosti pedagoškega delavca pomeni prepričanje, da je sposoben na učenje in motivacijo vplivati tudi pri otrocih, ki kažejo malo ali nič zanimanja (Woolfolk Hoy in Davis 2006). Pri samoučinkovitosti ne gre za samopodobo posameznika, saj gre za kognitivno in ne čustveno sodbo o lastni kompetentnosti (Schunk in Pajares 2002). M. Tschannen-Moran in A. Woolfolk Hoy (2001) sta ugotovili, da samoučinkovitost pedagoškega delavca združuje prepričanja o lastnih sposobnostih v okviru treh komponent: (i) poučevanja, 
(ii) motiviranja učencev in (iii) uravnavanja vedenja v razredu. Samoučinkovitost ima še posebej pomembno vlogo, ko se pedagoški delavec sooča s težavami na delovnem mestu, saj tisti z višjim občutkom samoučinkovitosti vlagajo več truda in kljub oviram dlje časa vztrajajo (Tschannen-Moran in Woolfolk Hoy 2001). Študije kažejo, da je prepričanje o višji samoučinkovitosti pedagoškega delavca povezano tudi z ugodnejšimi učnimi izzidi pri učencih (višja motivacija za učenje, učni dosežki in učenčeva lastna prepričanja o samoučinkovitosti, glej Tschannen-Moran in Woolfolk Hoy 2007), saj pedagoški delavci z višjo samoučinkovitostjo ustvarjajo spodbudnejše učno okolje za učenje (Bandura 2006).

Ugodnejše prepričanje o lastnih sposobnostih pa je povezano tudi s pozitivnejšimi psihološkimi posledicami za učitelje, na primer z višjim entuziazmom in večjo predanostjo poklicu (Tschannen-Moran in Woolfolk Hoy 2001). Raziskave namreč konsistentno kažejo (pregled v Aloe, Amo in Shanahan 2014; Skaalvik in Skaalvik 2010) pomembno negativno povezanost med samoučinkovitostjo učiteljev in komponentami izgorelosti, manj konsistentni pa so rezultati o smeri vpliva med konstruktoma. Brouwers in Tomic (2000) sta z longitudinalno študijo ugotovila, da čustvena izčrpanost vpliva na znižanje samoučinkovitosti, ta pa najprej na zmanjšanje osebne izpolnitve in kasneje na dvig depersonalizacije (Depolli Steiner 2011). Vendar so nekatere kasnejše longitudinalne študije pokazale, da samoučinkovitost vpliva na doživljanje izgorelosti in ne obratno (Aloe, Amo in Shanahan 2014; Schwarzer in Hallum 2008): višja samoučinkovitost naj bi v odnosu do izgorelosti nastopala kot zaščitni dejavnik (angl. stress buffer), ker zmanjšuje doživljanje stresa na delovnem mestu in motivira za uporabo učinkovitih strategij spoprijemanja z njim (Schwarzer in Hallum 2008).

Izmed treh zgoraj navedenih dimenzij samoučinkovitosti pedagoškega delavca so bile predhodne študije še posebej osredotočene na povezavo med samoučinkovitostjo na področju uravnavanja vedenja otrok v skupini in izgorelostjo pedagoških delavcev. Ugotovljeno je bilo, da ta dimenzija samoučinkovitosti napoveduje čustveno izčrpanost predvsem takrat, ko je zaznana samoučinkovitost nizka (Dicke idr. 2014). Osebe z nizko samoučinkovitostjo na področju uravnavanja vedenja menijo, da so v manjši meri sposobne nadzorovati skupino v smislu vzpostavljanja discipline, uvajanja pravil, učinkovitega odzivanja na neustrezno vedenje otrok ipd. Pedagoški delavci s temi prepričanji imajo v razredu več nemira in vedenjskih težav otrok, kar verjetno nadalje botruje višji čustveni izčrpanosti (Dicke idr. 2014). Prepričanja glede lastne sposobnosti uravnavanja vedenja $\mathrm{v}$ razredu so $\mathrm{v}$ največji meri povezana s poročano višjo osebno izpolnitvijo, sledi negativna 
povezanost omenjene komponente samoučinkovitosti z depersonalizacijo in čustveno izčrpanostjo (Aloe, Amo in Shanahan 2014; Wang, Hall in Rahimi 2015). Znižana samoučinkovitost, vezana na motiviranje učencev, pa je bila napovednik višje depersonalizacije in višje čustvene izčrpanosti (Wang, Hall in Rahimi 2015).

\section{Izgorelost in samoučinkovitost glede na delovno dobo}

Raziskovalci so preučevali tudi razlike v izgorelosti in samoučinkovitosti pedagoških delavcev glede na delovno dobo pedagoških delavcev. Ugotovljeno je bilo, da mlajši pedagoški delavci dosegajo višjo čustveno izčrpanost v primerjavi s starejšimi (Maslach, Jackson in Leiter 1997), za kar je literaturi navajajo več možnih vzrokov. Tako npr. mlajši zaposleni v primerjavi s starejšimi kot stresnejše zaznavajo več dogodkov na delovnem mestu, saj nekatere študije (npr. Manassero idr. 2006) kažejo, da se starost negativno povezuje $z$ zaznavanjem stresnosti več vidikov dela pedagoškega dela. Kot stresnejše so mlajši pedagoški delavci zaznavali: uravnavanje vedenja otrok, pomanjkanje časa za opravljanje delovnih nalog, neustrezno obnašanje učencev, konflikte z učenci, poučevanje nadomestnih predmetov in doživljanje manjše kompetentnosti, medtem ko so starejši pedagoški delavci kot stresnejši dejavnik zaznavali le obilico admininstrativnega dela na delovnem mestu.

Podobno o razlikah med starostnimi skupinami udeležencev $v$ študiji glede občutka samoučinkovitosti na delovnem mestu poročata tudi M. Tschannen-Moran in A. Woolfolk Hoy (2007), ki ugotavljata, da imajo pedagoški delavci začetniki (do 3 let delovnih izkušenj) nižjo samoučinkovitost (tako splošno samoučinkovitost kot tudi samoučinkovitost za poučevanje in za uravnavanje vedenja) kot pa izkušenejši učitelji (nad 4 leta izkušenj). Razlog naj bi bil v tem, da pedagoški delavci na začetku svoje poklicne poti še nimajo veliko lastnih izkušenj (Javrh 2007; Čotar Konrad in Štemberger 2018), ki predstavljajo enega izmed ključnih virov oblikovanja občutka samoučinkovitosti. Prepričanja o lastni učinkovitosti se namreč razvijajo na podlagi štirih virov: (i) s pomočjo lastnih izkušenj, (ii) preko posrednih izkušenj ( $z$ opazovanjem drugih), (iii) preko povratne informacije s strani drugih (prepričevanje, spodbude, nasveti) ter (iv) preko sovplivanja različnih psihofizičnih stanj (npr. tesnoba, ugodje), ki spremljajo izvedbo aktivnosti. Študija M. Tschannen-Moran in A. Woolfolk Hoy (2007) kaže, da so za učitelje začetnike pomembnejši napovedniki samoučinkovitosti povratne informacije s strani drugih in še vedno manj bogate lastne izkušnje, pri izkušenejših učiteljih pa samoučinkovitost napoveduje predvsem lastna izkušnja.

Slednje ugotovitve o razlikah $v$ stopnji samoučinkovitosti glede na de- 
lovno dobo pedagoških delavcev lahko smiselno utemeljimo tudi skozi modele profesionalnega razvoja učiteljev ${ }^{2}$ oz. modele poklicne rasti učiteljev, ki poteka na dveh medsebojno povezanih ravneh: (i) pojmovanja učitelja (tj. spoznavanje, sprejemanje in ponotranjenje pojmovanj poučevanja in učenja v procesu izkustveno-konstruktivističnega modela pouka) in (ii) učiteljeva ravnanja (pridobivanje in izpopolnjevanje poklicnih spretnosti). Učiteljeva pojmovanja vodijo njegovo akcijo, ki pomeni temeljno izhodišče za refleksijo, ta pa v povratni zanki nadalje ozavešča pojmovanja in izboljšuje pedagoška ravnanja (Marentič Požarnik 200o). Učitelj naj bi se s pridobivanjem izkušenj premikal od manjše k vse večji avtonomnosti, prožnosti in zmožnosti, ob tem pa iz učitelja začetnika postajal učitelj ekspert. Omenjeni proces so opisovali mnogi modeli profesionalnega razvoja učiteljev (več v Čotar Konrad in Štemberger 2018), vendar se bomo mi za namene pričujoče študije osredotočili zgolj na Hubermanov model profesionalnega razvoja (Huberman, Grounauer in Marti 1993) in iz tega izhajajočo slovensko verzijo S-modela profesionalnega razvoja učiteljev (preglednica 1) (podrobneje v Javrh 2007).

Glede na rezultate študij o izgorelosti in občutku samoučinkovitosti lahko sklepamo, da bodo pedagoški delavci prvega obdobja profesionalnega razvoja v primerjavi s kasnejšimi stopnjami profesionalnega razvoja poročali o višji stopnji izgorelosti in nižji stopnji samoučinkovitosti.

\section{Namen in cilji raziskave}

Glavni namen pričujoče študije je bil preveriti stopnjo izgorelosti med pomočnicami vzgojiteljic predšolskih otrok glede na delovno dobo in starostno skupino otrok, s katero delajo. Kot smo že omenili v teoretičnem delu prispevka, ugotavljamo pomanjkanje študij, ki se ukvarjajo z vprašanjem izgorelosti in občutka samoučinkovitosti pomočnic na različnih stopnjah profesionalnega razvoja. Čeprav se morebiti zdi, da so obremenitve na delovnem mestu tako učiteljev kot strokovnih delavk vrtca v nekaterih elementih podobne (interakcija in pričakovanja staršev otrok, sodelavci, soočanje s prevelikimi skupinami/razredi ipd), so zahteve delovnega mesta strokovnih delavk $v$ vrtcu zaradi večje razvojne občutljivosti in relativno manjše samostojnosti predšolskega otroka gotovo drugačne. Ker posledično ocenjujemo, da na osnovi študij izgorelosti učiteljev ne moremo neposredno sklepati na izgorelost in občutek samočinkovitosti strokovnih delavk $v$ vrtcu, smo v okviru raziskave želeli ugotoviti stopnjo izgorelosti in samoučinkovitosti pomočnic

\footnotetext{
${ }^{2}$ Termin »učitelj« je tukaj uporabljen kot generični pojem, s katerim želimo zaobjeti strokovne delavce vrtca in pedagoške delavce osnovnih šol.
} 
Preglednica 1 Prikaz temeljnih značilnosti Hubermanovega in S-modela profesionalnega razvoja učiteljev

\begin{tabular}{|c|c|c|c|}
\hline Hubermanov model & S-model & Usmerjenost & Ravnanja \\
\hline $\begin{array}{l}\text { Vstop v poklic, faza pre- } \\
\text { živetja in odkrivanja ( } 1 \\
\text { do } 3 \text { leta delovnih izku- } \\
\text { šenj). }\end{array}$ & $\begin{array}{l}\text { Preživetje in odkri- } \\
\text { vanje. }\end{array}$ & $\begin{array}{l}\text { Razumevanje te- } \\
\text { meljnih pravil in po- } \\
\text { stopkov. }\end{array}$ & $\begin{array}{l}\text { Togo upošteva na- } \\
\text { vodila: ni občutljiv } \\
\text { na kontekst dogaja- } \\
\text { nja. }\end{array}$ \\
\hline $\begin{array}{l}\text { Poklicna stabilizacija in } \\
\text { utrditev } \\
\text { ( } 4 \text { do } 6 \text { let delovnih iz- } \\
\text { kušenj). }\end{array}$ & Stabilizacija. & $\begin{array}{l}\text { Usmerjenost v kon- } \\
\text { tekst. Razvijanje ce- } \\
\text { lostnega ravnanja. }\end{array}$ & $\begin{array}{l}\text { Od pravil k situaciji: } \\
\text { pri odločanju in rav- } \\
\text { nanju že upošteva } \\
\text { dol. situacijo. }\end{array}$ \\
\hline $\begin{array}{l}\text { Poklicna aktivnost, eks- } \\
\text { perimentiranje ali vno- } \\
\text { vična ocenitev lastnega } \\
\text { dela, negotovost ( } 7 \text { do } \\
18 \text { let delovnih izku- } \\
\text { šenj). }\end{array}$ & $\begin{array}{l}\text { Poklicna } \\
\text { aktivnost/eksperi- } \\
\text { mentiranje ali } \\
\text { negotovost/revizija. }\end{array}$ & $\begin{array}{l}\text { Razvijanje splošnih } \\
\text { principov. }\end{array}$ & $\begin{array}{l}\text { Od situacije k na- } \\
\text { črtu: pri odločanju } \\
\text { in ravnanju ga vodi } \\
\text { splošni načrt. }\end{array}$ \\
\hline $\begin{array}{l}\text { Vedrina, distančni od- } \\
\text { nosi ali konservatizem } \\
\text { (19 do } 30 \text { let delovnih iz- } \\
\text { kušenj). }\end{array}$ & $\begin{array}{l}\text { Kritična odgovor- } \\
\text { nost ali sproščenost } \\
\text { ali nemoč. }\end{array}$ & $\begin{array}{l}\text { Povezovanje izku- } \\
\text { šenj v enovit scena- } \\
\text { rij. }\end{array}$ & $\begin{array}{l}\text { Od načrta k intuiciji: } \\
\text { pri odločanju in rav- } \\
\text { nanju ga vodi intui- } \\
\text { cija. }\end{array}$ \\
\hline $\begin{array}{l}\text { Poklicno slovo, ki se } \\
\text { kaže kot vedrina in } \\
\text { umirjenost ali zagrenje- } \\
\text { nost ( } 31 \text { do } 40 \text { let delov- } \\
\text { nih izkušenj). }\end{array}$ & $\begin{array}{l}\text { Izpreganje - spro- } \\
\text { ščeno ali zagre- } \\
\text { njeno. }\end{array}$ & $\begin{array}{l}\text { Oblikovanje prede- } \\
\text { lane in požlahtnjene } \\
\text { intuicije. }\end{array}$ & $\begin{array}{l}\text { Akcija in situacija } \\
\text { pomenita enako. }\end{array}$ \\
\hline
\end{tabular}

Opombe Povzeto po Javrh (2007) ter Čotar Konrad in Štemberger (2018).

pri prvi in pomočnic pri drugi starostni skupini otrok. Ob tem nas je zanimalo tudi, ali obstajajo razlike glede na stopnjo izgorelosti in občutek samoučinkovitosti glede na delovno dobo/stopnjo profesionalega razvoja pomočnic vzgojiteljic predšolskih otrok.

\section{Metodologija}

\section{Vzorec}

V študiji je sodelovalo 183 pomočnic vzgojitelja predšolskih otrok, od tega 174 $(95,1 \%)$ pomočnic in $9(4,9 \%)$ pomočnikov vzgojiteljev predšolskih otrok, $s$ povprečno starostjo 29,17 let ( $v$ razponu od 20 do 49 let). Vsi obiskujejo študijski program Predšolska vzgoja Pedagoške fakultete Univerze na Primorskem. Struktura vzorca glede na delovno dobo na področju predšolske vzgoje je glede na modela profesionalnega razvoja prikazana $v$ preglednici 2. Vključeni udeleženci pa so bili v šolskem letu 2018/2019 zaposleni kot delavci z 
Preglednica 2 Struktura vzorca udeležencev študije glede na stopnje profesionalnega razvoja po Huberman, Grounauer in Marti (1993), Čotar Konrad in Štemberger (2018) in po slovenskem S-modelu (Javrh 2007)

\begin{tabular}{llr}
\hline Hubermanov model & S-model & $f(\%)$ \\
\hline $\begin{array}{l}\text { Vstop v poklic, faza preživetja in odkrivanja (1 } \\
\text { do } 3 \text { leta delovnih izkušenj). }\end{array}$ & Preživetje in odkrivanje. & $88(48,1)$ \\
\hline $\begin{array}{l}\text { Poklicna stabilizacija in utrditev (4 do 6 let de- } \\
\text { lovnih izkušenj). }\end{array}$ & Stabilizacija. & $26(14,2)$ \\
\hline $\begin{array}{l}\text { Poklicna aktivnost, eksperimentiranje ali vno- } \\
\text { vična ocenitev lastnega dela, negotovost (7 }\end{array}$ & $\begin{array}{l}\text { Poklicna aktiv- } \\
\text { nost/eksperimentiranje ali } \\
\text { do 18 let delovnih izkušenj). }\end{array}$ & $61(33,3)$ \\
\hline $\begin{array}{l}\text { Vedrina, distančni odnosi ali konservatizem } \\
\text { (19 do 30 let delovnih izkušenj). }\end{array}$ & $\begin{array}{l}\text { Kritična odgovornost ali spro- } \\
\text { ščenost ali nemoč. }\end{array}$ & $8(4,4)$ \\
\hline $\begin{array}{l}\text { Poklicno slovo, ki se kaže kot vedrina in umir- } \\
\text { jenost ali zagrenjenost (31 do 40 let delovnih }\end{array}$ & $\begin{array}{l}\text { Izpreganje - sproščeno ali za- } \\
\text { grenjeno. }\end{array}$ & \\
izkušenj). & & \\
\hline
\end{tabular}

različnimi starostnimi skupinamo, od tega jih je bilo dobra tretjina v prvi (69; $37,7 \%)$ in nekoliko več v drugi starostni skupini 81 (44,3\%), preostali udeleženci v vrtcu niso bili zaposleni trenutno (33; 18,0\%), ampak v prejšnjih šolskih letih.

\section{Pripomočki}

Izgorelost na delovnem mestu. Vprašalnik izgorelosti (Maslach Burnout Inventory - prirejeno po Maslach in Jackson 1981) je sestavljen iz 22 trditev, ki se nanašajo na izgorelost na delovnem mestu, in vključuje tri dimenzije: čustveno izčrpanost ( $v$ nadaljevanju $\breve{C})$, odtujen odnosa do dela (tj. depersonalizacija, v nadaljevanju D) in zmanjšane osebne izpolnjenosti ( $v$ nadaljevanju OI). Udeleženci na vprašalniku s pomočjo 7-stopenjske lestvice pogostosti (o - nikoli; 1 - nekajkrat na leto; 2 - enkrat na mesec; 3 - nekajkrat na mesec; 4 enkrat na teden; 5 - nekajkrat na teden; 6 - vsak dan) označijo, kako pogosto doživijo ali občutijo posamezne situacije. Glede na različne predhodne študije (npr. Demerouti idr., 2001;) vprašalnik kaže zadovoljivo zanesljivost in veljavno faktorsko strukturo vprašalnika, podobno velja za psihometrične značilnosti slovenske verzije vprašalnika (Depolli Steiner 2011). Koeficienti notranje skladnosti pričujoče študije za čustveno izčrpanost znašajo o,95, za depresonalizacijo o,84, za podlestvico osebne izpolnjenosti pa 0,92.

Samoučinkovitost na delovnem mestu. V študiji smo uporabili krajšo verzijo Lestvice samoučinkovitosti učiteljev (Teacher's sense of efficacy scale TSES, Tschannen-Moran in Woolfolk-Hoy 2001; slovenska verzija Čotar Konrad 
2015), ki meri tri komponente samoučinkovitosti: instrumentalno učinkovitost, učinkovito uravnavanje vedenja strokovnih delavcev $v$ skupini otrok in učinkovitost pri motiviranju otrok za učenje. Notranja zanesljivost lestvice iz slovenskih predhodnih študij (Čotar Konrad 2015) kaže zadovoljive vrednosti notranje skladnosti $(0,86)$, pri čemer se koeficienti notranje zanesljivosti posameznih komponent lestvice gibljejo od o,78 do o,81.

\section{Postopek in obdelava podatkov}

Spletno obliko baterije testov smo pripravili v novembru 2018 in jo poslali na skupni spletni naslov udeležencev, ki jim je bila ves čas raziskave zagotovljena anonimnost. Vprašalnik je bil dostopen dva meseca. Pridobljene podatke smo obdelali s statističnim paketom SPSS 25.0. Najprej smo analizirali deskriptivne vrednosti podatkov in preverjali normalnost njihove porazdelitve. Analiza normalnosti porazdelitve odgovorov na posameznih podlestvicah je pokazala, da porazdelitev ni normalna, zato smo v nadaljevanju za ugotavljanje razlik glede na delovno dobo strokovnih delavk in glede na skupino, v kateri delujejo, uporabljali neparametrične teste. Povezanost posameznih dimenzij izgorelosti in komponent zaznanega občutka učinkovitosti na delovnem mestu smo preverjali s Spearmanovim $\rho$ koeficientom.

\section{Rezultati in razprava}

Glavni namen študije je bil preveriti stopnjo izgorelosti in občutka samoučinkovitosti strokovnih delavk v vrtcu ter medsebojno povezanost omenjenih konceptov. Nadalje pa nas je zanimalo, ali obstajajo razlike v poročani stopnji izgorelosti in samoučinkovitosti strokovnih delavk glede na delovno dobo (in s tem ustrezno stopnjo profesionalnega razvoja po Huberman, Grounauer in Marti 1993) ter glede na starostno skupino otrok, s katerimi trenutno delajo.

Najprej smo preverili opisne statistike in normalnost distribucij posameznih merjenih spremenljivk (preglednica 3). Rezultati izraženosti posameznih dimenzij izgorelosti kažejo, da strokovne delavke v povprečju poročajo o nizki stopnji čustvene izčrpanosti in depersonalizacije ter o visoki stopnji osebne izpolnjenosti na delovnem mestu. Takšna izraženost posameznih dimenzij izgorelosti nakazuje, da pomočnice v povprečju poročajo o nizki izgorelosti. Dobljeni podatki se ne ujemajo s predhodnimi študijami na vzorcih pedagoških delavcev (npr. Radic Hozo, Sucic in Zaja 2015; Depolli Steiner 2011), ki kažejo na visok odstotek (okrog 50 \%) pedagoških delavcev, ki občutijo ali kažejo znake izgorelosti. Skladno z raziskavo K. Depolli Steiner (2011) o učiteljih tudi pomočnice vzgojiteljic našega vzorca depersonalizacijo doživljajo zelo redko. Izredno nizka samoocena na lestvici depersonalizacije pri 
Preglednica 3 Opisne statistike dimenzij izgorelosti in samoučinkovitosti

\begin{tabular}{lrrrrrrrrrrr}
\hline Dimenzija & & $N$ & Min & Max & $M$ & $s$ & $A s$ & $s$ & $S p l$ & $s$ & $K S$ \\
\hline Izgorelost & $(1)$ & 183 & 0,00 & 4,67 & 1,38 & 1,03 & 0,96 & 0,18 & 0,28 & 0,36 & $0,13^{* * *}$ \\
& $(2)$ & 183 & 1,75 & 6,00 & 4,75 & 0,92 & $-0,84$ & 0,18 & 0,48 & 0,36 & $0,09^{* *}$ \\
& $(3)$ & 183 & 0,00 & 3,00 & 0,35 & 0,56 & 2,22 & 0,18 & 5,31 & 0,36 & $0,28^{* * *}$ \\
\hline Samoučin- & $(4)$ & 183 & 2,75 & 5,00 & 4,05 & 0,47 & 0,06 & 0,18 & $-0,21$ & 0,36 & $0,15^{* * *}$ \\
kovitost & $(5)$ & 183 & 3,00 & 5,00 & 4,06 & 0,49 & 0,08 & 0,18 & $-0,26$ & 0,36 & $0,21^{* * *}$ \\
& $(6)$ & 183 & 3,00 & 5,00 & 3,95 & 0,50 & 0,40 & 0,18 & $-0,41$ & 0,36 & $0,15^{* * *}$
\end{tabular}

Opombe Naslovi vrstic: (1) čustvena izčrpanost, (2) osebna izpolnjenost, (3) depersonalizacija, (4) instrumentalna, (5) uravnavanje vedenja, (6) motivacija. $N$ - numerus; $M$ - aritmetična sredina; s - standardna deviacija, Min/max - najnižja in najvišja vrednost; $A s$ - asimetričnost; Spl - sploščenost; KS - Kolmogorov-Smirnov koeficient; ${ }^{* *}$ koeficient KS je statistično pomemben na nivoju $p<0.01 ;{ }^{* *}$ koeficient KS je statistično pomemben na nivoju $p<0.001$.

populaciji pedagoških delavcev ni povsem nepričakovana, saj nekateri raziskovalci opozarjajo, da učitelji postavke na tej lestvici zaznavajo kot manj primerne ter se zato skušajo izogniti odgovarjanju ali podajajo bolj socialno zaželene odgovore in so rezultati zato pogosto omejeni (Benita, Butler in Shibaz 2019). V primeru uporabe drugih vprašalnikov so raziskovalci (Benita, Butler in Shibaz 2019) na lestvici depersonalizacije dobili bolj razpršene rezultate.

Po drugi strani pa analize podatkov kažejo (preglednica 3) na visoko stopnjo samoučinkovitosti na področju instrumentalne učinkovitosti in učinkovitega uravnavanja vedenja otrok v skupini; pomočnice izražajo nekoliko nižjo kompetentnost pri motivaciji otrok za učenje v dejavnostih. To pomeni, da pomočnice poročajo o tem, da učinkovito znajo in zmorejo otrokom podati alternativne razlage o pojavu, ki ga ne razumejo, da se čutijo kompetentne pri implementaciji alternativnih strategij poučevanja v skupini. Podobno poročajo visoko stopnjo samoučinkovitoti na področju uravnavanja in usmerjanja vedenja otrok v skupini ali umirjanja otroka, ki je bodisi nemiren ali se drugače neustrezno vede. O nekoliko nižji kompetentnosti pomočnice poročajo na področju spodbujanja otrokove motivacije za delo, pri čemer se ocenjujejo kot manj sposobne motivirati otroka, ki za sodelovanje kaže manj interesa, oz. otroka, ki manj zaupa v lastne sposobnosti.

Povezanost posameznih dimenzij izgorelosti in komponent zaznanega občutka učinkovitosti na delovnem mestu pokaže (glej preglednico 4) pomembno povezanost med vsemi merjenimi variablami. Ugotavljamo lahko, da strokovne delavke, ki poročajo o višji stopnji osebne izpolnitve na delovnem mestu, poročajo o višjem občutku učinkovitosti tako na področju pomoči in izvedbe dejavnosti (instrumentalna komponenta) kot tudi na pod- 
Preglednica 4 Povezanost med dimenzijami izgorelosti in komponentami samoučinkovitosti

\begin{tabular}{|c|c|c|c|}
\hline \multirow[t]{2}{*}{ Izgorelost } & \multicolumn{3}{|c|}{ Samoučinkovitost } \\
\hline & Inštrumentalnost & Uravnavanje vedenja & Motivacija \\
\hline Čustvena izčrpanost & $-0,257^{* *}$ & $-0,231^{* *}$ & $-0,205^{* *}$ \\
\hline Osebna izpolnjenost & $0,535^{* *}$ & $0,394^{* *}$ & $0,384^{* *}$ \\
\hline Depersonalizacija & $-0,276^{* *}$ & $-0,197^{* *}$ & $-0,273^{* *}$ \\
\hline
\end{tabular}

Opombe ${ }^{* *}$ Spearmanov $\rho$ koeficient statistično pomemben na nivoju $p<0.01$.

ročju uravnavanja vedenja otrok $v$ skupini (komponenta uravnavanja vedenja $v$ skupini) in motiviranja otrok za sodelovanje v dejavnostih ter učenju. Rezultati niso presenetljivi, saj sta si konstrukta samoučinkovitosti in osebne izpolnitve $v$ določeni meri sorodna in medsebojno povezana.

Kot poročajo mnoge študije (Aloe, Amo in Shanahan 2014; Dicke idr. 2014; Skaalvik in Skaalvik 2010), tudi rezultati dotične raziskave (preglednica 4) potrjujejo negativno pomembno povezanost med samoučinkovitostjo in ključnima pokazateljema izgorelosti posameznika, torej čustveno izčrpanostjo in depersonalizacijo. Ugotavljamo namreč nizko do zmerno negativno pomembno povezanost med dimenzijo čustvene izčrpanosti in vsemi komopnentami samoučinkovitosti. Podoben vzorec povezanosti lahko razberemo tudi med komponentami samoučinkovitosti in depersonalizacije, kar pomeni, da strokovne delavke, ki poročajo o višjem občutku odtujenosti od dela, pomembno pogosteje poročajo o nižji stopnji samoučinkovitosti na delovnem mestu. Prav tako je vzorec korelacij med dimenzijami samoučinkovitosti in izgorelosti zelo podoben povezavam predhodnih študij, kjer so ugotovili, da se dimenzije samoučinkovitosti v najvišji meri povezujejo z osebno izpolnjenostjo, $v$ najnižji pa s čustveno izčrpanostjo (Wang, Hall in Rahimi 2015). Manjše odstopanje od predhodnih študij (Aloe, Amo in Shanahan 2014; Wang, Hall in Rahimi 2015), ki pa so bile izvedene na učiteljih, je v tem, da se samoučinkovitost glede uravnavanja vedenja $v$ našem primeru močneje povezuje $s$ čustveno izčrpanostjo kot pa $z$ depersonalizacijo. Slednje pomeni, da strokovne delavke v primerjavi z učitelji z morebitno nižjo stopnjo občutka samoučinkovitosti na področju uravnavanja vedenja otrok pogosteje poročajo predvsem o lastni čustveni izčrpanosti in manj pogosto o depersonalizaciji, tj. občutku oddaljenosti od otrok, povečani ciničnosti in zaznavanju otrok le še kot objektov. Čeprav je naša raziskava korelacijska in ne dopušča interpetacije o smeri vpliva med samoučinkovitostjo in izgorelostjo, pa iz predhodnih longitudinalnih raziskav (Schwarzer in Hallum 2008) vemo, da je samoučinkovitost zaščitni dejavnik in napovednik izgorelosti. 
Nizka stopnja izgorelosti v našem vzorcu se zato smiselno povezuje $z$ visoko izraženostjo vseh treh komponent samoučinkovitosti.

$V$ nadaljevanju nas je zanimalo, ali obstajajo razlike $v$ stopnji izgorelosti in poročani stopnji samoučinkovitosti glede na delovno dobo na področju predšolske vzgoje. Udeležence študije smo glede na delovno dobo razdelili v skupine profesionalnega razvoja glede na Hubermanov in S-model (Javrh 2007), in sicer so bile v raziskavo vključene štiri skupine: (i) skupina začetnikov $v$ t. i. preživetveni fazi in fazi odkrivanja, ki šele vstopa na področje vzgoje in izobraževanja (o-3 leta delovne dobe); (ii) skupina $v$ fazi stabilizacije $v$ poklicu (4-6 let delovne dobe); (iii) skupina v fazi aktivnega eksperimentiranja - negotovosti (7-18 let delovne dobe) in (iv) skupina sproščenosti v poklicu - občutka nemoči (19-30 let delovne dobe). V preglednici 5 prikazujemo razlike v dimenijah izgorelosti in občutka samoučinkovitosti glede na delovno dobo. Zaradi premajhnega števila pomočnic z najdaljšo delovno dobo, te skupine $v$ interpretacijo ne bomo zajeli.

Rezultati kažejo (preglednica 5), da pomočnice ne poročajo o različni stopnji izgorelosti na delovnem mestu, ampak se razlike glede na delovno dobo v profesionalnem delovanju kažejo pri dveh komponentah samoučinkovitosti. Tako ugotavljamo, da o najvišji stopnji instrumentalne samoučinkovitosti poročajo strokovne delavke $v$ fazi poklicne stabilizacije, kar pomeni, da se $v$ primerjavi z drugimi strokovnimi delavkami ocenjujejo kot kompetentnejše na področju uporabe različnih strategij za spremljanje otrokovega napredka in poznavanja različnih načinov dela z otroki. Glede na vzorec dotične študije (pomočnice vzgojiteljic) težko govorimo o samostojnem načrtovanju in izvajanju dejavnosti, saj delovno mesto pomočnice vzgojiteljic predšolskih otrok tega ne zahteva, gotovo pa lahko trdimo, da strokovne delavke $v$ stadiju stabilizacije pogosteje kot strokovne delavke $v$ začetnem stadiju (do 3 let delovne dobe) profesionalnega razvoja poročajo o poznavanju in rabi različnih strategij spremljanja otrokovega napredka in spodbujanja njegovega učenja. Podoben vzorec razlik med skupinama o oceni samoučinkovitosti strokovnih delavk ugotavljamo tudi pri zaznani kompetentnosti na področju motiviranja otrok za učenje. Tako o najvišji stopnji samoučinkovitosti na področju motivacije poročajo strokovne delavke v obdobju poklicne stabilizacije, nato v obdobju eksperimentiranja na poklicnem področju, kot najmanj kompetentne pa se na področju motiviranja otrok za učenje zaznavajo novinke pomočnice vzgojitelja predšolskih otrok (preglednica 5). Na osnovi omenjenega lahko sklepamo, da je ključno vprašanje, kateri dejavniki vplivajo na oblikovanje samoučinkovitosti ob koncu študija in na začetku kariere. Kot so pokazale raziskave (Tscahnnen-Moran in Woolfolk Hoy 2007), se namreč zaradi 
Preglednica 5 Razlike $v$ dimenzijah izgorelosti in samoučinkovitosti glede na delovno dobo strokovnih delavk

\begin{tabular}{|c|c|c|c|c|c|c|}
\hline Dimenzija & & Del. doba (let) & $N$ & $\bar{R}$ & $H$ & $\bar{p}$ \\
\hline \multirow[t]{12}{*}{ Izgorelost } & \multirow[t]{4}{*}{ Čustvena izčrpanost } & $0-3$ & 88 & 94,93 & 3,50 & 0,32 \\
\hline & & $4^{-6}$ & 26 & 74,15 & & \\
\hline & & $7-18$ & 61 & 94,44 & & \\
\hline & & $19-30$ & 8 & 99,13 & & \\
\hline & \multirow[t]{4}{*}{ Osebna izpolnjenost } & $0-3$ & 88 & 91,71 & 0,15 & 0,99 \\
\hline & & $4-6$ & 26 & 89,06 & & \\
\hline & & $7-18$ & 61 & 93,24 & & \\
\hline & & $19-30$ & 8 & 95,31 & & \\
\hline & \multirow[t]{4}{*}{ Depersonalizacija } & $0-3$ & 88 & 94,99 & 1,35 & 0,72 \\
\hline & & $4-6$ & 26 & 82,23 & & \\
\hline & & $7-18$ & 61 & 91,81 & & \\
\hline & & $19-30$ & 8 & 92,31 & & \\
\hline \multirow{12}{*}{$\begin{array}{l}\text { Samoučin- } \\
\text { kovitost }\end{array}$} & \multirow[t]{4}{*}{ Instrumentalna } & $0-3$ & 88 & 81,76 & 8,29 & $0,04^{*}$ \\
\hline & & $4-6$ & 26 & 112,08 & & \\
\hline & & $7-18$ & 61 & 98,62 & & \\
\hline & & $19-30$ & 8 & 88,94 & & \\
\hline & \multirow[t]{4}{*}{ Uravnavanje vedenja } & $0-3$ & 88 & 84,34 & 6,93 & 0,07 \\
\hline & & $4-6$ & 26 & 104,46 & & \\
\hline & & $7-18$ & 61 & 100,87 & & \\
\hline & & $19-30$ & 8 & 68,19 & & \\
\hline & \multirow[t]{4}{*}{ Motivacija } & $0-3$ & 88 & 76,94 & 15,80 & $0,001^{*-*}$ \\
\hline & & $4-6$ & 26 & 115,10 & & \\
\hline & & $7-18$ & 61 & 104,29 & & \\
\hline & & $19-30$ & 8 & 88,94 & & \\
\hline
\end{tabular}

Opombe $N$-numerus; $\bar{R}$ - povprečni rang; $H$ - Kruskal-Wallisov test; ${ }^{*}$ razlika je statistično pomembna na nivoju 0,$05 ;{ }^{* *}$ razlika je statistično pomembna na nivoju o,01.

pomanjkanja lastnih izkušenj na začetku kariere pri oblikovanju občutka samoučinkovitosti začetnik močneje opira na druge vire, kot so npr. posredne izkušnje z opazovanjem drugih, občutja ob izvajanju dejavnosti ter prejeta povratna informacija in spodbuda s strani drugih (npr. starši, sodelavci, vodstvo). Ker začetna samoučinkovitost vpliva na nadaljnje vedenje in pridobivanje izkušenj pedagoškega delavca (npr. koliko vztraja, vlaga trud in ali pri reševanju problemov na delovnem mestu išče nove rešitve ipd.), omenjeno vedno znova vodi v potrjevanje obstoječih prepričanj o lastni učinkovitosti. Na tem mestu je torej pomembno razmisliti tudi o vprašanju praktičnega usposabljanja, pomenu vpliva mentorstva ter začetnih izkušenj, ki jih strokovne 
Preglednica 6 Razlike $v$ dimenzijah izgorelosti in samoučinkovitosti glede na starostno skupino otrok, v kateri strokovne delavke trenutno delujejo

\begin{tabular}{llllrrr}
\hline Dimenzija & & Skupina & $N$ & $\bar{R}$ & $U$ & $p$ \\
\hline Izgorelost & Čustvena izčrpanost & Prva & 69 & 64,67 & 3707,00 & 0,06 \\
& & Druga & 81 & 84,73 & & \\
\cline { 2 - 7 } & Osebna izpolnjenost & Prva & 69 & 83,10 & 3831,00 & 0,77 \\
& & Druga & 81 & 69,02 & & \\
\cline { 2 - 7 } & Depersonalizacija & Prva & 69 & 68,68 & 3942,00 & 0,98 \\
& & Druga & 81 & 81,31 & & \\
\hline Samoučin- & Instrumentalna & Prva & 69 & 80,36 & 3553,50 & 0,27 \\
\cline { 3 - 7 } & & Druga & 81 & 71,36 & & \\
\cline { 2 - 7 } & Uravnavanje vedenja & Prva & 69 & 76,48 & 3582,50 & 0,30 \\
& & Druga & 81 & 74,67 & & \\
\cline { 2 - 7 } & Motivacija & Prva & 69 & 77,78 & 3208,00 & $0,03^{*}$ \\
& & Druga & 81 & 73,56 & & \\
\hline
\end{tabular}

Opombe $N$-numerus; $\bar{R}$ - povprečni rang; $U$-Mann-Whitneyev koeficient; ${ }^{*}$ razlika je statistično pomembna na nivoju 0,05.

delavke začetnice pridobijo na delovnem mestu. Menimo namreč, da bi prav sistematično in visoko strokovno vodeno ter izvedeno praktično usposabljanje bodočih strokovnih delavk $v$ vrtcu lahko pomembno olajšalo in pripomoglo $k$ višjemu občutku samoučinkovitosti na delovnem mestu ter zmanjševalo možnosti za izgorelost strokovnih delavk.

V okviru tretjega raziskovalnega vprašanja smo ugotavljali razliko v poročani stopnji izgorelosti in občutkom samoučinkovitosti glede na to, v kateri starostni skupini otrok trenutno delujejo strokovne delavke.

Analiza dimenzij izgorelosti pokaže, da v stopnji izgorelosti ni statistično pomembnih razlik glede na to, $s$ katero starostno skupino trenutno delajo strokovne delavke, opazimo pa lahko nakazan trend $v$ dimenziji čustvene izčrpanosti, pri čemer pomočnice pri delu z drugo starostno skupino izražajo večjo stopnjo čustvene izčrpanosti kot pomočnice pri delu s prvo. Podobno poročajo tudi predhodne študije (Rentzou 2015), ki pravijo, da strokovne delavke v drugi starostni skupini občutijo višjo čustveno izčrpanost kot strokovne delavke $v$ prvi.

Analiza dimenzij samoučinkovitosti pa pokaže (preglednica 6) razlike zgolj $v$ eni komponenti samoučinkovitosti, natančneje $v$ tem, $v$ kolikšni meri se strokovne delavke čutijo kompetentne vzpodbujati in ohranjati motivacijo otrok za učenje. Ugotavljamo, da strokovne delavke, ki so trenutno zaposlene v prvi starostni skupini, poročajo o višjem občutku kompetentnosti za 
vzpostavljanje in spodbujanje motivacije otrok za učenje. Slednje pomeni, da sebe ocenjujejo kot sposobnejše za to, da otroke spremljajo in pohvalijo ob dobro opravljenih nalogah, da otrokom osmislijo učenje in posledično krepijo njihov interes za učenje ter sodelovanje v pripravljenih dejavnostih.

\section{Sklepi}

V raziskavi smo preučevali izraženo stopnjo izgorelosti na delovnem mestu in občutka samoučinkovitosti, pri čemer so nas zanimale razlike $v$ merjenih konceptih med pomočnicami vzogjiteljic, ki delajo z različnimi starostnimi skupinami otrok, ter razlike glede na stopnjo profesionalnega razvoja strokovnih delavk. Rezultati kažejo, da je poročana stopnja izgorelosti razmeroma nizko izražena, saj pomočnice kažejo visoko stopnjo osebne izpolnitve na delovnem mestu ter nižjo stopnjo čustvene izčrpanosti in depersonalizacije, ugotavljamo pa lahko trend, ki se nakazuje $v$ dimenziji čustvene izrpanosti pomočnic, ki delajo z drugo starostno skupino. Iz omenjenega lahko sklepamo, da bi bilo smiselno in potrebno - upoštevajoč spoznanje, da je preučevanje izgorelosti zaposlenih na predšolski stopnji v Sloveniji empirično močno podhranjeno - podrobneje preučiti vprašanje dejavnikov izgorelosti strokovnih delavk v vrtcih. Dejstvo je namreč, da je koncept izgorelosti bistveno kompleksnejši kot zgolj merjenje posameznih dimenzij, ki nakazujejo posameznikovo izčrpanost. V raziskavi nismo preučevali organizacijskih dejavnikov, ki skupaj z osebnostnimi dimenzijami pomembno sovplivajo na doživljanje komponent izgorelosti (Benita, Butler in Shibaz 2019; Maslach, Schaufeli in Leiter 2001). Kot poudarja C. Maslach (2003), pa bi se bilo potrebno na sistemskem nivoju usmeriti ne le $v$ zmanjševanje izgorelosti, temveč predvsem $v$ opolnomočenje strokovnih delavk in podporo za doseganje dimenzije osebne izpolnjenosti na delovnem mestu, torej občutka moči, učinkovitosti in predanosti nalogam na delovnem mestu. Ena izmed ključnih dimenzij doseganja osebne izpolnjenosti je tudi visok občutek samoučinkovitosti na delovnem mestu, ki ga je podobno kot koncept izgorelosti potrebno obravnavati celostno (Fakler in Malmberg 2016). Pomočnice $v$ dotični študiji namreč poročajo o razmeroma visokem občutku samoučinkovitosti, pri čemer se kažejo razlike glede dimenzije učinkovitega motiviranja otrok za dejavnosti: pomočnice, ki delujejo v prvi starostni skupini, ugodneje ocenjujejo občutek samoučinkovitosti na področju spodbujanja motivacije otrok kot pomočnice $v$ drugi starostni skupini. Poročana samoučinkovitost je različna tudi glede na stopnjo profesionalnega razvoja strokovnih delavk, pri čemer pomočnice $v$ začetni fazi (do 3 leta delovne dobe) občutijo najnižjo samoučinkovitost, pomočnice $v$ fazi poklicne stabilizacije pa najvišjo 
stopnjo samoučinkovitosti na delovnem mestu. Iz omenjenega lahko sklepamo, da je pri oblikovanju občutka samoučinkovitosti na delovnem mestu ključnega pomena prepoznavati vire, na osnovi katerih pomočnice na različnih stopnjah profesionalnega razvoja in pri opravljanju delovnih nalog z različnimi starostnimi skupinami oblikujejo prepričanja o lastnih sposobnostih na delovnem mestu. Eden ključnih momentov v tem razvoju je prepoznavanje pomena prakse ob zaključku šolanja in mentoriranja pomočnic začetnic ob vstopanju na delovno mesto.

\section{Literatura}

Al-Adwan, F., E. Zaid in M. M. Al-Khayat. 2017. „Psychological Burnout in Early Childhood Teachers: Levels and Reasons." International Education Studies 10 (1): 179-189.

Aloe, A. M., L. C. Amo in M. E. Shanahan. 2014. "Classroom Management SelfEfficacy and Burnout: A Multivariate Meta-Analysis."Educational Psychology Review 26:101-126.

Bandura, A. 1986. Social Foundation of Thought and Action: A Social Cognitive Theory. Englewood Cliffs, NJ: Prentice Hall.

- 2006. »Adolescent Development from an Agentic Perspective.« V SelfEfficacy Beliefs of Adolescents, ur. T. Urdan in F. Pajeres, 1-44. Greenwich, CT: Information Age Publishing.

Bakker, A. M., E. Demerouti in W. B. Schaufeli. 2002. "Validation of the Maslach Burnout Inventory - General Survey: An Internet Study across Occupations." Anxiety, Stress, and Coping 15:245-260.

Baran, G., M. Y. Biçakçi, F. Inci, M. Öngör, A. Ceran in G. Atar. 2010. »Analysis of Burnout Levels of Teachers."Procedia Social and Behavioral Sciences 9:975980.

Benita, M., R. Butler in L. Shibaz. 2019. „Outcomes and Antecedents of Teacher Depersonalization: The Role of Intrinsic Orientation for Teaching. « Journal of Educational Psychology 111 (6): 1103-1118.

Brouwers, A., in W. Tomic. 2000. »A Longitudinal Study of Teacher Burnout and Perceived Self-Efficacy in Classroom Management."Teaching and Teacher Education 16:239-253.

Čotar Konrad, S. 2015. „Validacija nove lestvice profesionalnega razvoja pedagoškega delavca.«Pedagoška obzorja 30 (3-4): 118-135.

Čotar Konrad, S., in T. Štemberger. 2018. Children Matter: Empowering Teachers for Generations to Come. Schriften zur pädagogischen Psychologie 70. Hamburg: Kovač.

Demšar, I. 2003. »Sindrom izgorelosti pri učiteljih.« Magistrsko delo, Univerza v Ljubljani.

Depolli Steiner, K. 2011. »lzgorelost osnovnošolskih učiteljev.« Vzgoja in izobraževanje 42 (4): 72-32. 
Dicke, T., H. W. Marsh, P. D. Parker, M. Kunter, A. Schmeck in D. Leutner. 2014. "Self-Efficacy in Classroom Management, Classroom Disturbances, and Emotional Exhaustion: A Moderated Mediation Analysis of Teacher Candidates." Journal of Educational Psychology 106 (2): 569-583.

Fakler, S., in L. Malmberg. 2016. »Teachers' Self-Efficacy in 14 OECD Countries: Teacher, Student Group, School and Leadership Effects."Teaching and Teacher Education 56:185-195.

Huberman, M., M. Grounauer in J. Marti. 1993. The Lives of Teachers. London: Cassell.

Javrh, P. 2007. »Fazni model razvoja kariere slovenskih učiteljev.« Sodobna pedagogika 58 (5): 68-87.

Jeon, L., C. K. Buettner in A. A. Grant. 2018. »Early Childhood Teachers' Psychological Well-Being: Exploring Potential Predictors of Depression, Stress, and Emotional Exhaustion.« Early Education and Development 29 (1): 53-69.

Košir, K., M. Licardo, S. Tement in K. Habe. 2014. »Doživljanje stresa in izgorelosti, povezanih z delom z učenci s posebnimi potrebami pri učiteljih v osnovni šoli.«Psihološka obzorja 23:110-124.

Manassero, M. A., E. Garcia Buades, G. Torrens, C. Ramis, A. Vazquez in V. A. Ferrer 2006. »Teacher Burnout: Attributional Aspects. Psychology in Spain 10 (1): 66-74.

Marentič Požarnik, B. 2000. Psihologija učenja in pouka. Ljubljana: DZS.

Maslach, C. 2003. Burnout: The Cost of Caring. Cambridge: Malor Books.

Maslach, C., in M. Leiter. 1997. The Truth about Burnout. San Fracisco: JosseyBass.

Maslach, C., in S. E. Jackson. 1981. »The Measurement of Experienced Burnout.« Journal of Organizational Behaivor 2 (2): 99-113.

Maslach, C., S. E. Jackson in M. P. Leiter. 1997. »Maslach Burnout Inventory.« In Evaluating Stress: A Book of Resources, ur. C. P. Zalaquett in R. J. Wood, 191218. Lanham, MD: Scarecrow Education.

Maslach, C., W. B. Schaufeli in M. P. Leiter. 2001. »Job Burnout.« Annual Review of Psychology 52 (1): 397-422.

Radic Hozo, E., G. Sucic in I. Zaja. 2015. »Burnout Syndrome Among Educators in Pre-School Education.«Materia Sociomedica 27 (6): 399-403.

Rentzou, K. 2015. »Prevalence of Burnout Syndrome of Greek Child Care Workers and Kindergarten Teachers." Education 3-13 43 (3): 249-262.

Rutar, S. 2018. »Kakovost šole s perspektive učencev s priseljensko izkušnjo kot izhodišče za zagotavljanje inkluzivnega izobraževanja." Dve domovini: razprave o izseljenstvu 48:109-127.

Rutar, V. 2019. »Zaznavanje in posledice stresa pri vzgojiteljih in učiteljih v slovenskih vzgojno-izobraževalnih ustanovah: doktorska disertacija.« Doktorska disertacija, Univerza na Primorskem.

Schunk, D. H., in F. Pajares. 2002. »The Development of Academic Self-Efficacy.« 
V Development of Achievement Motivation, ur. A. Wigfield in J. S. Eccles, 1531. San Diego, CA: Academic Press.

Schwarzer, R., in S. Hallum. 2008. »Perceived Teacher Self-Efficacy as a Predictor of Job Stress and Burnout: Mediation Analyses. « Applied Psychology 57:152171.

Skaalvik, E. M., in S. Skaalvik. 2010. »Teacher Self-Efficacy and Teacher Burnout: A Study of Relations." Teaching and Teacher Education 26:1059-1069.

Slivar, B. 2009. Raziskava o poklicnem stresu pri slovenskih vzgojiteljih in učiteljih. Ljubljana: SVIZ.

_ 2013. Na poti k dobremu počutju: obvladovanje stresa $v$ šoli - teoretični vidik: knjiga za ravnatelje in učitelje o obvladovanju stresa na ravni šole in na ravni posameznika. Ljubljana: Zavod RS za šolstvo.

Tsai, E., L. Fung in L. Chow. 2006. "Sources and Manifestations of Stress in Female Kindergarten Teachers. «International Education Journal 7 (3): 364370.

Tschannen-Moran, M., in A. Woolfolk Hoy. 2001. »Teacher Efficacy: Capturing an Elusive Construct." Teaching and Teacher Education 17:783-805.

- 2007. »The Differential Antecedents of Self-Efficacy Beliefs of Novice and Experienced Teachers."Teaching and Teacher Education 23:944-956.

Wang, H., N. C. Hall in S. Rahimi. 2015. »Self-Efficacy and Causal Attributions in Teachers: Effects on Burnout, Job Satisfaction, Illness, and Quitting Intentions. "Teaching and Teacher Education 47:120-130.

Woolfolk Hoy, A., in H. Davis. 2006. „Teacher Self-Efficacy and Its Influence on the Achivement of Adolescents. "V Self-Efficacy Beliefs of Adolescents, ur. T. Urdan in F. Pajeres, 117-133. Greenwich, CT: Information Age Publishing.

Zakon o vrtcih (ZVrt-UPB2). 2005. Uradni list Republike Slovenije, št. 100.

\section{Burnout and Self-Efficacy of Preschool Teachers in Kindergarten}

The aim of the study was to determine preschool teachers' level of the burnout and level of self-efficacy. We also wanted to establish whether there were any differences in burnout and in self-efficacy according to preschool teachers age group position and according to the level of professional development. We found out that the reported level of burnout is relatively low, as preschool teachers show a high level of personal fulfillment at the workplace and a lower level of emotional exhaustion and depersonalisation. Also, relatively high level of self-efficacy was reported by preschool teachers, showing differences in selfefficacy components: preschool teachers who work in the first age group (13 years old) reported higher level of self-efficacy in supporting child motivation in comparison to preschool teachers working who work in the second age group (3-6 years old). Reported self-efficacy is also different regarding the level of professional development, where the novice preschool teacher ( 1 to 3 years of work experience) felt the lowest level of self-efficacy, while the preschool 
teachers in the phase of professional stabilization reported the highest level of self-efficacy in the kindergarten.

Keywords: burnout, self-efficacy, preschool teachers, professional development 